\title{
The Role of Pronouns in English, Persian, and Azerbaijani Languages
}

\author{
Sima H. Haghnazari \\ Technical and Vocational University of Urmia, Urmia, Iran
}

\begin{abstract}
In general, in order to state the concept of relativity, pronoun plays a specific role. In some languages such as English, even the possessive pronoun exists alone, it can also be created in the nouns that are stated with personal pronoun. English possessive pronouns are divided into two half groups from the point of usage view in conversation: (1) Different aspects of using possessive pronouns are independent (without noun); and (2) The followings are independently cases of using possessive. Some of the linguists describe personal pronouns as possessive pronouns from the point of concept view. It should be mentioned here that personal pronouns is not able to state the concept of possession by itself. In Persian language, there are not any other possessive pronouns to have independent meanings. In comparing personal pronouns from the point of their mode, concept or their usage in Azerbijan or Persian languages, some of their specifications such as their similarity or their differences are interesting.
\end{abstract}

Keywords: possessive, pronouns, personal, language

\section{Introduction}

Since the second kind of these pronouns (see Table 1) have more usages and which are directly related with nouns, their relativity concept of usage is not so important. In translating these kinds of pronouns into Azerbijan language, their independent possessive aspects are mostly used. For example: This car is hers-bu mashine onundur (onunkudur).

Table 1

Pronouns in English

\begin{tabular}{|l|l|l|}
\hline Persons & Singular & Plural \\
\hline First person & Mine & Ours \\
\hline Second person & Yours & Yours \\
\hline Third person & His, hers, and its & Theirs \\
\hline
\end{tabular}

It is also possible to confront with identical pronouns, however, they are accepted as independent pronouns in Azerbijan language (see Examples 1-5).

Example (1) Personal pronouns:

Sima H. Haghnazari, doctor, English Department, Technical and Vocational University of Urmia. 
Deyirsan siza taza mashine yollayiblar, ha? (You say that they have sent you a new car. Don't you?)

San ozun onu yazdin? (Did you write it yourself?)

Here the words: "ozun", "san", and "biza" are personal pronouns.

Example (2) Demonstrative pronouns:

Kecan hafta hamin kitabi aldim. (I bought the same book last week.)

Mana bu kitablari yolladi. (He sent me these books.)

Here the words "hamin" and "bu" are demonstrative pronouns.

Example (3) Interrogative pronouns:

Siz na ucun bura galmadiz? (Why didn't you come here?)

San kimi gurdun? (Whom did you see?)

In these examples, the words "na ucun (why)" and "kimi (whom)" are interrogative questions.

Example (4) Obscure pronouns:

Har has istasa uzuna guc verib hirslana bildiyi halda, basina guc verib dusuna bilarmi? (S.

Rahimov). In this example "har kas" is obscure pronoun.

Example (5) Assignment pronoun:

Butun talabalar imtahani yaxsi verdilar. (All the students took their exams well.)

The word "butun (all)" is an assignment pronoun (Hosseinzadeh, 2007, p. 97).

As you see, Hosseinzadeh (2007) has stated only five kinds of pronouns, but while speaking about personal pronouns, he stated several pronouns. Since personal pronouns are able to explain the concept of possessive and nominative pronouns, they can conditionally be divided into three parts: (1) specific personal pronouns; (2) binary personal pronouns; and (3) nominative personal pronouns.

While speaking about binary personal pronouns, the author writes: "To indicate possession, possessive endings are added to specific pronoun". It is also possible to add the suffixes: ku-ki-ki-ku (possessive indicators) to personal pronouns which have possessive endings. For example: manimki-saninki-onunku-bizimkionlarinki-sizinki (Hosseinzadeh, 2007, p. 103).

Hosseinzadeh has formed a separate diagram to use possessive pronouns and has stated different kinds of examples on possessive personal pronouns, and he has also compared them with suffixes: ku-ku-ki-ki are used after binary suffixes (Hosseinzadeh, 2007, p. 104). However, in Azerbijan linguistics, the concept of possessive personal pronouns is not wholly accepted. In connection with this matter in the book Contemporary Azerbijan Language (1980, Chapter 2), it has been written: "Personal pronoun that as taken the form of possessive suffix is often called a kind of pronoun as possessive personal pronoun" (Budakhova, 1980, p. 510).

After this, the authors wrote: "There is not any possessive pronoun in Azerbijan language. Personal pronouns in Azerbijan language function as possessive pronouns. In other words, personal pronouns having the mode of possessive suffixes function as possessive pronouns" (Budakhova, 1980, p. 156). It is interesting to know that in the 1951's edition of the same book, the possessive pronouns have been presented separately and divided into two groups. To state possessive mode to main personal pronouns, the possessive endings are added. For example: The words manim-sanin—onunun-bizim—sizin-onlarin are added to main personal pronouns 
having possessive endings for example, $\mathrm{ki}$, indicated possessive mode in some cases: manimki-saninki_onunku-bizimki-onlarinki-sizinki (Dmitriev, 1951, p. 91). Since we will talk about this point in other chapters, we explain only this point here that possessive pronouns are not accepted in Azerbijan language. In contemporary English, the adjective pronouns that are not used alone exist in the following forms ${ }^{1}$ :

(My-your-his-her-its-our-your-their)

My father was a St. Bernard, my mother was a collie, but I am a Presbyterian (Twain, n.d.).

My mother had a fondness for such; she liked to say them, and see other dogs look surprised and envious, as wondering how she got so much education (Twain, n.d.).

I know that I missed many a meal, in spite of the fact that I could "throw my feet" with the next one when it came to "slamming a gate" for a "poke-out" or a "set-down" or hitting for a "light piece" on the street (London, n.d.).

It is not my business to teach you to spell, said Gertrude, taking the pen (Shaw, n.d.).

You come to work to-morrow, and in the middle of the day I'll advance you enough for your dinner (London, n.d.).

Did you give your son the name of Ham, because you lived in a sort of ark? (Dickens, n.d.).

He went to India with his capital, and there, according to a wild legend in our family, he was once seen riding on an elephant, in company with a Baboon; but I think it must have been a Baboo-or a Begum (Dickens, n.d.).

My little one, you see, going round with me to have a peep at her father's birds (Dickens, n.d.).

It was as if some great house had shut its doors and windows against approach (Henry, n.d.).

Word must be sent to our partisans in the palace, and a signal agreed upon (Henry, n.d.).

Whether, like your friend Carlyle, we will "give up things" for our faith's sake (Jerome, n.d.).

How else do you think you are going to attract their attention? he asked her (Jerome, n.d.).

Comparing Azerbijan with Persian languages: "In comparing personal pronouns from the point of their mode, concept or their usage in Azerbijan or Persian languages, some of their specifications such as their similarity or their differences are interesting" (Rostamova, 1998, p. 116). Following this statement, he showed nine similar and different aspects that we explain some of them: The first and most important aspect that is also interesting is the first singular person which is identical whether in mode or in concept: man (I). As Rostamov (1998) pointed out, the other main point in Farsi is using several words instead of personal pronouns. One of the special specifications on personal pronouns in Farsi is that a group of words are used instead of personal pronouns. The most important of these are: (1) first singular person instead of pronoun; and (2) second singular and plural person indicate pronoun.

As it is seen from the examples, although the words used instead of personal pronouns function as subject, from the point of concept (logically) in quantity and in person, it is according with the predicate; but in grammar, it does not accord with predicate (Rostamov, 1998, p. 120) since there is not a separate personal pronoun in Farsi, therefore, when a personal pronoun is substituted in place of them, it is described personal pronoun by linguists. Sadikhova (1975) who researches on personal pronouns in Farsi, stated here:

Some of the linguists describe personal pronouns as possessive pronouns from the point of concept view. It should be mentioned here that personal pronouns is not able to state the concept of possession by itself. In Persian language there are not any other possessive pronouns to have independent meanings. Personal pronouns have possessive concepts only in the form of syntax. (p. 12)

In definition of syntax, their function to indicate the relativity is also its syntactic obligation. Therefore,

${ }^{1}$ The author selected the following citations from http//www.gutenberg.org. 
there are not any special possessive pronouns (Sadikhova, 1975, p. 12). In fact, we also think that the concept of possession in the content of syntax does not indicate the concept of possessive pronoun. So we also agree that in Persian language, the personal pronouns play an important role in stating the possessive concept. In general, in old Iranian languages such as old Persian, because of existing different ranks of time, personal pronouns also contain special time forms in passing from old Persian to middle Persian.

In relation to abolishing this flexibility, departing grammatical time endings and other transformations have been occurred. In grammatical structure, the independent personal pronouns existing in old Persian which have lost their subjective form in Middle Persian, but preserved their possessive form ( the subjective form of the first singular person is an exception). In Middle Persian, we can only relate the usage of possessive pronouns to a apostrophe's structure. Different forms of personal pronouns in Middle Persian have been entered into modern Persian after some kinds of as "ban" with phonetic changes. For example: Nezami Khodiev (1997) in his book; the history of literal Azerbijan language has written about "Ezzaddin Hassan Oghlu", the author of the first poems in Azerbijan Turkish language: "Hassan Oghlu's lyrics is a reliable source and document in clarifying several grammatical orders. Here 13 or 14 cases are considered on grammatical literal written form" (Khodiev, 1997, p. 185). In the presented poem which has seven verses, we are confronted with the first singular person as "man" also "ban". In the poem the pronoun "san" (you ) - the second person, is also seen:

$\underline{\text { Mən }}$ ölsəm, $\underline{\text { sən }}$ büti-şəngül, sürahi eyləmə qülqül;

Nə qülqül-qülqüli-badə, nə badə-badeyi-əhmər;

Başımdan getməz hərgiz səninlən içdiyim badə;

Nə badə-badeyi-məsti, nə məsti- məsteyi-sağər.

In the second lyric from Hassan Oghlu (n.d.), we are faced with more personal pronouns. The interesting point is: On the contrary of the first lyric, the first singular person has different phonetic form, for example:

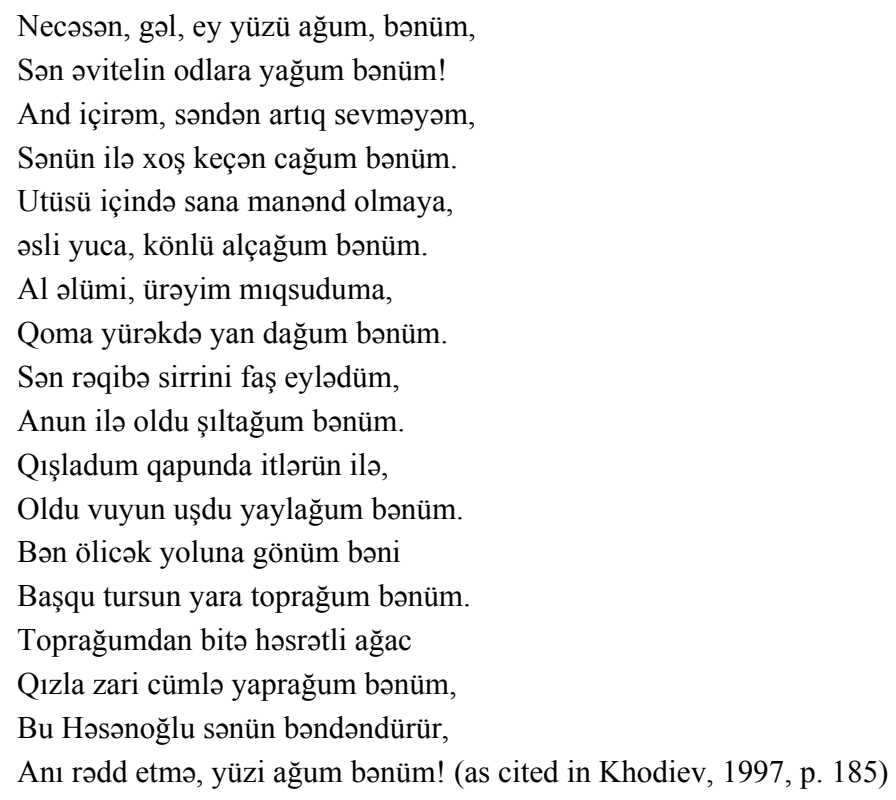

As you see in the poem, the personal pronoun is used in relation to each three persons and we can say that it 
has been unchanged in contemporary Azerbijan and there has not been any change in its meaning or its form. The only difference is that the first and second personal pronouns are used today as they were used in the past.

As an example we read a symbol here quoted by "Saber" hundred years later:

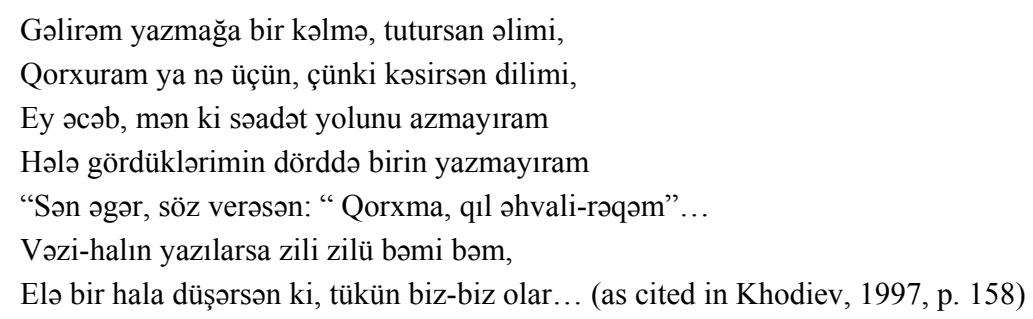

In fact, this immobility indicates that the morphological structure (identifiable form) of Azerbijan language is highly fixed and unchanged. But in Hassan Oghlu's poem, the interesting point is the second and third singular person used in apostrophe's form that is different from what is used in the form of apostrophe's pronoun. In a form that in third singular person instead of pronoun $(\mathrm{O}-\mathrm{he})$, the pronoun onun is used and instead of "ban", the pronoun "banim" is used, but we have not confronted with such a structure in Azerbijan in historical grammar books. The same form also exists during the following years. For example, while surveying morphological specifications used in the book Divan (2005) written in the 15th century by Roza Ivazov who was famous in Azerbijan literature, she stated that relativity endings (suffixes) used in Azerbijan language have the same usage in Contemporary Azerbijan Language. For example, in singular persons the suffixes: im-im-um-um have been used: "Kecdi omrum nale vu zari bila sandan iraq". The same mode exists in the cases of all pronouns. Only in creating the second singular person's suffix with immovable, "Noon" (n) is specified to that era of Azerbijan and other Turkish languages, it has lost its usage in the contemporary Azerbijan today.

The existing difference can be shown and this is mostly seen in phonetic variation (Ivazov, 2005, pp. 27-31). Once more the mentioned matters prove the researchers' statement that there have been the slightest changes in Turkish languages during the several past hundred years, but in comparison to Turkish languages, there is not such an invariability in other languages.

\section{Conclusions}

To state the concept of relativity, pronoun plays a specific role. In some languages such as English, even the possessive pronoun exists alone, it can also be created in the nouns that are stated with personal pronoun. In Persian language, the personal pronouns play an important role in stating the possessive concept. In general, in old Iranian languages such as old Persian, because of the existing different ranks of time, personal pronouns also contain special time forms. In passing from old Persian to middle Persian, there have been the slightest changes in Turkish languages during the several past hundred years, but in comparison to Turkish languages, there is not such an invariability to other languages.

\section{References}

Budakhova, Z. (1980). Contemporary Azerbaijani language (p. 510). Baku: Elm. Dickens, C. (n.d.). Little Dorrit. Retrieved from http://www.gutenberg.org 
Dmitriev, N. K. (1951). Common grammatical categories. The grammer of Azerbaijan language (pp. 89-97). Baku: Maarif. Henry, O. (n.d.). Roads of destiny. Retrieved from http://www.gutenberg.org

Hosseinzadeh, M. (2007). Modern Azerbaijani language (p. 280). Baku: Sharq-Qarb.

Ivazova, R. D. (2005). Morphological specifications (Keshvari language) (p. 370). Baki: Elm.

Jerome, J. K. (n.d.). All roads lead to Calvary. Retrieved from http://www.gutenberg.org

Khodiev, N. (1997). The history of literal Azerbijan language (p. 491). Ankara: Yargıcı Ofset.

London, J. (n.d.). The road. Retrieved from http://www.gutenberg.org

Moosaev, O. (2003). Englesh grammer. Baku: Maarif.

Rostamova, T. (1998). Comparative grammar of the Persian and Azerbaijani languages (p. 294). Tehran: Mihan.

Sadikhova, J. (1975). Person pronouns at the Persian language (the historical aspect) (p. 180). Baku: Elm.

Shaw, G. B. (n.d.). An unsocial socialist. Retrieved from http://www.gutenberg.org

Twain, M. (n.d.). A dog's tale. Retrieved from http://www.gutenberg.org 